\title{
Solid Phase Extraction Utilization for Colorimetric Determination of Zinc in Waters, Food, Milk, and Biological Samples
}

\author{
Alaa S Amin ${ }^{1 *}$, Sayed MN Moalla ${ }^{2}$ and Mohammed AG Khalil' \\ ${ }^{1}$ Department of Chemistry, Faculty of Science, Benha University, Egypt \\ ${ }^{2}$ Department of Chemistry, Faculty of Science, Port Saied University, Egypt
}

\begin{abstract}
A highly rapid, sensitive, and selective method for the determination of zinc based on the reaction of zinc(II) with 5-amino-2-(phenyldiazenyl)phenol (ACDP) and/or 5-amino-2-(ptolyldiazenyl)phenol (ATDP) and the solid phase extraction of the $\mathrm{Zn}$ (II)- ACDP and/or ATDP complex with Amberlite XAD-2000 was developed, in the presence of $\mathrm{pH}=5.6$ and 6.2 using ACDP and ATDP, respectively, and Triton X-114 medium. ACDP and/or ATDP reacts with zinc to form a violet complex with a molar ratio of 2:1 (ACDP and/or ATDP to zinc). This complex was enriched by the solid phase extraction with Amberlite XAD-2000. An enrichment factor of 500 was obtained by elution of the complex from the resin with a minimal amount of isopentyl alcohol $(0.2 \mathrm{ml})$. In isopentyl alcohol medium, the molar absorptivity of the complex is $1.13 \times$ $10^{6}$ and $1.37 \times 10^{6} \mathrm{~L} / \mathrm{mol} \mathrm{cm}$ at 647 and $662 \mathrm{~nm}$ using ACDP and ATDP, respectively, against a reagent blank prepared in a similar way without zinc. Beer's law is obeyed in the range of 5.0$160 \mathrm{ng} / \mathrm{ml}$ in the measured solution. The relative standard deviation for 10 replicate samples of $50 \mathrm{ng} / \mathrm{ml}$ level is 1.26 and $1.47 \%$, respectively. The detection and quantification limits reaches 1.5 and $4.7 \mathrm{ng} / \mathrm{ml}$ in the original samples. The presented procedure was successfully applied for determination of zinc content in real samples such as waters, food, milk, and biological samples with satisfactory results.
\end{abstract}

\section{Keywords}

Solid phase extraction, Colorimetry, Azo dyes, Zinc determination, Environmental analysis

\section{Introduction}

Some trace heavy metals are considered to be among the vital micronutrients, and they have a wide range of biochemical functions in all living organisms [1-3]. Zinc is one of the significant ingredients of proteins involved in intermediary metabolism, hormone secretion pathway, and immune system, and its enzymes participate in synthesis and decomposition of proteins, lipids, carbohydrates, and nucleic acids $[4,5]$. Zinc deficiency might lead to several disorders such as growth retardation, diarrhea, immunity depression, eye and skin lesions, malfunction of wound healing, and other skin diseases [6]. In order to observe the symptoms and trace element absorption, a biological sample such as blood is often analyzed. Deficiency in trace elements including deviation of zinc from its normal level in blood is used for early diagnosis of certain

*Corresponding author: Alaa S Amin, Department of Chemistry, Faculty of Science, Benha University, Benha, Egypt Accepted: August 20, 2019; Published: August 22, 2019

Copyright: (C) 2019 Amin AS, et al. This is an open-access article distributed under the terms of the Creative Commons Attribution License, which permits unrestricted use, distribution, and reproduction in any medium, provided the original author and source are credited.

Amin et al. Int J Analyt Bioanalyt Methods 2019, 1:006 
diseases [7]. Moreover, metabolic disorders of zinc are thought to be associated with a number of neurological diseases such as Alzheimer, Parkinson, Epilepsy, and Hypoxia-ischemia [8]. Although trace metals like zinc are vital for humans, the excess utilization can be harmful and toxic, and thus it should be used according to physiological needs.

Due to the importance of analysis of zinc ions in trace levels, separation and enrichment of trace zinc in complex matrix should be considered, and the purification of processed liquids containing heavy metal ions requires meticulous attention. Modern instrumental methods including spectrometry, inductively coupled plasma mass spectrometry (ICP-MS), inductively coupled plasma atomic emission spectrometry (ICP-AES), atomic absorption spectrometry (AAS) [9-11] have been used for determination of traces of metal ions in various fields. However, direct determination of metal ions at trace levels by flame atomic absorption spectrometry (FAAS), spectrophotometry [12-14] and electroanalytical techniques [7] are limited not only due to insufficient sensitivity, but also to matrix interference. Under these circumstances, in order to determine trace levels of $\mathrm{Zn}$ a separation and enrichment step may be beneficial prior to their determinations. A wide range of sorbents has been applied to metal ion preconcentration by solid phase extraction technique and these include: Silica gel, resins, alumina oxide, cellulose, activated carbon, chitosan, metal-organic frameworks, modified conductive polymers, grapheme and titanium oxides [15-28]. The most popular polymer resin styrene - divinylbenzene (S-DVB) demonstrates good sorption capacity, high surface area, and good chemical and physical stability. However, owing to its insufficient selectivity, structure modifications are often made on the sorbent. Compared to classical methods, spectrochemical methods are more acceptable alternatives due to their relatively low cost, simple operation and wide spread diffusion of equipments [29].

Among preconcentration methods, solid phase extraction has some advantages over other preconcentration methods in view of: (i) Ease regeneration of solid phase; (ii) High preconcentration factor; (iii) Reusability of the adsorbent; (iv) Low consumption of reagents; (v) Ease of automation; (vi) Ecofriend methods; (vii) Ease usage. The most extensively used solid phase extractants are modi- fied C-18 silica [30], activated carbon [31], alumina [32,33] and Amberlite XAD resins [34-36]. It would appear that the most successful and popular applications of SPE are to use Amberlite resins (polystyrene-divinyl benzene polymer), because of good adsorption properties such as large surface areas and good hydrophobic nature.

However, the use of Amberlite XAD-2000 resin in Amberlite XAD resin series is limited in preconcentration studies [34,37,38]. Amberlite XAD-2000 is a polystyrene-divinylbenzene copolymer having specific surface area: $620 \mathrm{~m}^{2} / \mathrm{g}$, dipole moment: 0.3 , pore size: $4.5 \mathrm{~nm}$ and bead size: $20-50$ mesh [30]. Because of these important properties, it has selected as a solid phase extractant in this work.

Routine spectrophotometric methods are often not sensitive enough to determine low concentrations of zinc ions in environmental samples only at the $\mu \mathrm{g} \mathrm{L}^{-1}$ level. Consequently, a preconcentration step is usually required. Solid phase extraction is an attractive technique because of its notable advantages $[39,40]$. In this paper, ACDP and/or ATDP was first used as a chromogenic reagent for zinc. Based on the color reaction of ACDP and/or ATDP with zinc, in the presence of $\mathrm{pH}=5.6$ and 6.2 , respectively and Triton X-114 medium. The solid phase extraction of the colored complex with Amberlite XAD-2000, a highly sensitive, selective and rapid method for the determination of zinc in environmental samples was developed. The method was successfully applied for determination of zinc content in real samples such as food, milk, waste and drinking waters, and biological samples with satisfactory results.

\section{Material and Methods}

\section{Instruments}

A Perkin Elmer Lambda 12 UV-Visible spectrophotometer with a $5.0 \mathrm{~mm}$ quartz cell was used for all spectral measurements. An Orion research model $601 \mathrm{~A}$ /digital ionalyzer $\mathrm{pH}$ meter was used for checking the $\mathrm{pH}$ of solutions. The extraction was performed on a Waters Solid Phase Extraction (SPE) device (that can prepare 20 samples simultaneously), and Amberlite XAD-2000 were used. The samples were passed through the resin in a forward direction and the retained complex was eluted in a reverse direction. A Perkin Elmer atomic absorption spectrometry model A Analyst 300 was used for all GFAAS measurements. 


\section{Reagents}

All chemicals used were of analytical grade unless otherwise stated. All of the solutions were prepared with deionized water obtained from a Milli-Q50 SP Reagent Water System (Millipore Corporation, USA). Isopentyl alcohol (Fisher Corporation, USA) was used. ACDP and/or ATDP used in the present investigation was prepared according to the procedure described previously [41]. A stock $2 \times 10^{-3} \mathrm{M}$ solution of ACDP and/or ATDP was prepared by dissolving an appropriate weight of the reagent in a minimum amount of pure ethanol and brought to $100 \mathrm{ml}$ in a calibrated flask with ethanol.

Amberlite XAD-2000 resin having $0.25-0.48 \mathrm{~mm}$ particle size from Sigma (RT 1-0393) was grinded to $0.1-0.2 \mathrm{~mm}$ and washed with the procedure reported previously [42].

The stock solution of zinc(II) was prepared by dissolving a proper amount of analytical grade zinc(II) nitrate in $100 \mathrm{ml}$ of deionized water. One $\mathrm{ml}$ of dilute nitric acid was added to this solution to prevent the hydrolysis of zinc ions. The working solutions of zinc were prepared by accurate stepwise dilution of the stock solution with deionized water.

Universal buffer solutions of $\mathrm{pH}$ values ranging from 2.4 to 12.0 were prepared as recommended earlier [43]. Triton X-114 solution [2.0\% (v/v)] was prepared by dissolving Triton X-114 with water.

\section{General procedure}

To a standard or sample solution containing no more than $16 \mu \mathrm{g}$ of $\mathrm{Zn}(\mathrm{II}), 7.5 \mathrm{ml}$ of universal buffer solution [43] at $\mathrm{pH} 5.6$ and 6.2 using ACDP and ATDP, respectively, were added. After that, 3.0 $\mathrm{ml}$ of $2 \times 10^{-3} \mathrm{M}$ ACDP and/or ATDP solution dissolved in pure ethanol and $5.0 \mathrm{ml}$ of $2.0 \%$ Triton $\mathrm{X}-114$ solution were added. The pale pink mixture was diluted to a volume of $100 \mathrm{ml}$ with deionized water and mixed well. After $5.0 \mathrm{~min}$, the solution was passed through Amberlite XAD-2000 at a flow rate of $20 \mathrm{ml} / \mathrm{min}$ with changing the color to violet. After the enrichment had finished, the retained complex was eluted from the resin with $0.2 \mathrm{ml}$ of isopentyl alcohol at a flow rate of $1.0 \mathrm{ml} / \mathrm{min}$. The absorbance of the eluant was measured in a 5.0 $\mathrm{mm}$ cell at 647 and $662 \mathrm{~nm}$ using ACDP and ATDP, respectively, against a reagent blank prepared in a similar way without zinc.

\section{Water samples treatment}

The water samples analyzed were collected in pre-washed (with detergent, deionized water, dilute nitric acid and deionized water, respectively) polyethylene bottles. The samples were filtered through a Millipore cellulose membrane of pore size $0.45 \mu \mathrm{m}$. The samples were stored in $1.0 \mathrm{~L}$ polyethylene bottles and acidified to $1.0 \%$ with nitric acid and were subsequently stored at $4.0^{\circ} \mathrm{C}$ in a refrigerator. In order to eliminate the chlorine in tap water, the samples were treated for $5.0 \mathrm{~min}$ with $5.0 \mathrm{~g}$ of activated charcoal and filtered before being transferred into a polyethylene bottle. Before the analysis, the $\mathrm{pHs}$ of the samples were adjusted to 8.5 to neutralize the excess nitric acid.

\section{Food samples treatment}

The food samples analyzed were brought from the local market. The samples cleaned and dried in open air, preventing them from mineral contamination. The dried sample was pulverized in a mortar for the purpose of analysis, to a convenient small size $(300 \mu \mathrm{m})$. Ten grams of the powdered leafy/ chilli or $10 \mathrm{ml}$ of milk sample was taken in a silica crucible, heated to oxidize organic matter, and ashed at $550{ }^{\circ} \mathrm{C}$, in a muffle furnace for $4.0-5.0 \mathrm{~h}$. The ash was then dissolved by heating with $10 \mathrm{ml}$ of 2.0 M nitric acid, filtered through an acid, washed filter paper (Whatman No. 41) and then washed with hot water. The filtrate and washings were collected in a $25 \mathrm{ml}$ volumetric flask and finally, made up to the mark with deionized water.

\section{Meat samples treatment}

Meat samples were purchased in local markets. These samples were triturated, homogenized, freezedried, and then kept in clean, dry containers. After sieving, fractions with particle size under $100 \mu \mathrm{m}$ were taken. an amount of $0.5 \mathrm{~g}$ of sample was mixed with $2.0 \mathrm{M}$ nitric acid in a glass beaker and heated on a hot-plate until complete sample dissolution. Once cool, the solution was transferred into a $100 \mathrm{ml}$ calibrated flask and made up to volume with deionized water with subsequent zinc determination by the above general and FAAS procedures.

\section{Biological samples treatment}

The human hair sample was rinsed with acetone, chloroform and deionized water and then 


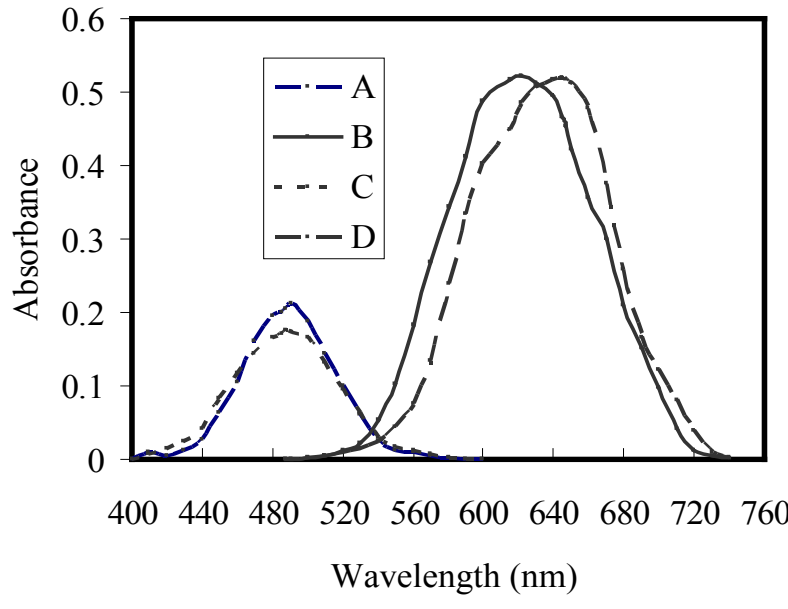

Figure 1: Absorption spectra for ACDP and ATDP and there complexes of $100 \mathrm{ng} / \mathrm{ml}$ of $\mathrm{Zn}(\mathrm{II})$.

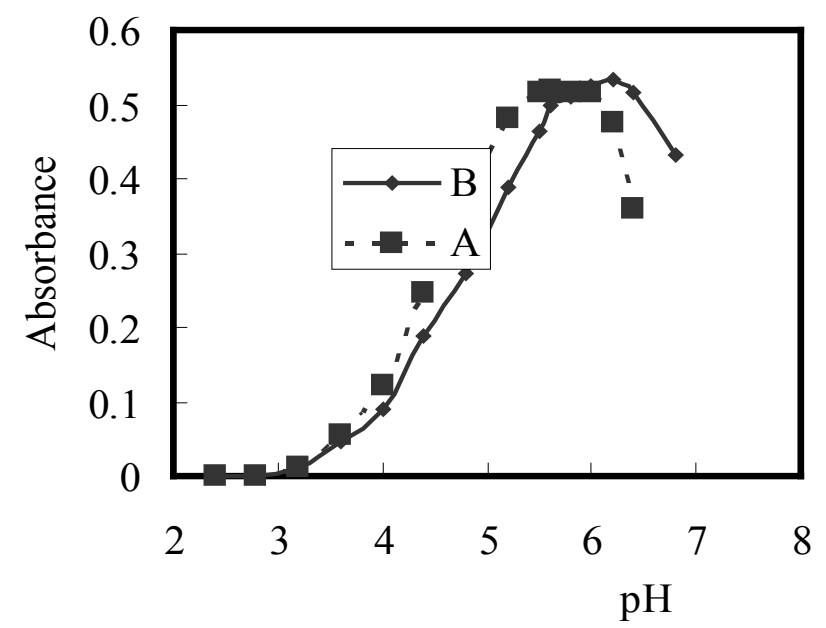

Figure 2: Effect of $\mathrm{pH}$ on the complexation of $100 \mathrm{ng} /$ $\mathrm{ml} \mathrm{Zn(II)} \mathrm{using} \mathrm{A-} \mathrm{ACDP} \mathrm{and} \mathrm{B-} \mathrm{ATDP.}$

was dried at $60^{\circ} \mathrm{C}$. An exact weight of sample $(0.5$ g) was treated with $3.0 \mathrm{ml}$ of $10 \mathrm{M} \mathrm{H}_{2} \mathrm{SO}_{4}$ and $30 \mathrm{ml}$ of $5.0 \mathrm{M}$ nitric acid and was heated on a hot plate at $150{ }^{\circ} \mathrm{C}$ for $30 \mathrm{~min}$. Finally, about $25 \mathrm{ml}$ of $30 \% \mathrm{H}_{2} \mathrm{O}_{2}$ solution were gradually added until the solution turned colorless and was heated nearly to dryness at $200{ }^{\circ} \mathrm{C}$ to yield a whitish residue. Approximately $5.0 \mathrm{ml}$ of $0.1 \mathrm{M}$ nitric acid was added to the beaker and the contents were heated at $100^{\circ} \mathrm{C}$ for $15 \mathrm{~min}$. The $\mathrm{pH}$ of solution was adjusted to 8.5 to neutralize the acidic media, and diluted to $100 \mathrm{ml}$ in a conical flask. $5.0 \mathrm{ml}$ of this solution were then analyzed according to the given procedure.

Rat femur, kidney and feces samples were prepared using a closed vessel microwave oven. An accurate $( \pm 0.1 \mathrm{mg}$ ) mass of each sample $(\approx 460 \mathrm{mg}$ femur, $\approx 315 \mathrm{mg}$ kidney and $\approx 114 \mathrm{mg}$ feces sam- ples) was transferred to polyfluoroethylene (PFA) vessels. The femur sample, before microwave digestion, was kept for $12 \mathrm{~h}$ in contact with concentrated nitric acid. The samples were mixed with nitric acid, carried into the pressurized microwave oven (maximum $1.03 \times 10^{6} \mathrm{~Pa}$ ) and irradiated for 75 min at $100 \mathrm{~W}$ (maximum). Thereafter, the obtained solutions were treated with $30 \% \mathrm{H}_{2} \mathrm{O}_{2}$, transferred into volumetric flasks and diluted to the appropriate volume with deionized water. An aliquot (10-50 $\mathrm{ml}$ ) of the sample solution was taken individually and zinc was determined by the general procedure.

\section{Results and Discussion}

\section{Absorption spectra}

The absorption spectra of ACDP and ATDP and their Zn(II) complexes in isopentyl alcohol medium are shown in Figure 1 . The absorption bands of ACDP and its zinc complex are located at $478 \mathrm{~nm}$ and $647 \mathrm{~nm}$, whereas for ATDP and its zinc complex are located at $491 \mathrm{~nm}$ and $662 \mathrm{~nm}$.

\section{Effect of acidity}

The results showed that the optimal $\mathrm{pH}$ for the reaction of $\mathrm{Zn}$ (II) with ACDP is 5.4-5.8, whereas that for ATDP is 6.0-6.44. A pH 5.6 and 6.2 universal buffer solution was recommended to control the $\mathrm{pH}$ for ACDP and ATDP respectively, (Figure 2). The use of $6.0-9.0 \mathrm{~mL}$ of pH 5.6 and 6.2 buffer solution per $100 \mathrm{ml}$ was found to give a maximum and constant absorbance. Therefore, $7.5 \mathrm{ml}$ of $\mathrm{pH} 5.6$ and 6.2 buffer solution was recommended, since the results are highly concordant using ACDP and ATDP respectively.

\section{Effect of surfactants}

The Zn-ACDP and/or ATDP complexes has poor solubility in water solution. It is required to add a suitable amount of surfactants to enhance the solubility of the complex. The experiments showed that all the anionic, nonionic and cationic surfactants are effective in enhancing solubility. In addition to enhancing solubility, in the nonionic (Triton X-114, Triton X-100, Tween-80, Tween-60, Emulsifier-OP) and cationic (CTMAB CPB CPC) surfactants medium, the sensitivity of the $\mathrm{Zn}-\mathrm{ACDP}$ and/ or ATDP complexes was also increased markedly. The effect of the nonionic and cationic surfactants on improving sensitivity is recorded in Table 1 . The results showed that Triton X-114 was the best additive surfactant and that the use of $4.0-6.0 \mathrm{~mL}$ 
Table 1: The effect of surfactants on the Zn(II)- ACDP and/or ATDP chromogenic system.

\begin{tabular}{|c|c|c|c|c|c|c|c|c|c|}
\hline Surfactant & Ligand & СТМАВ & CPB & CPC & $\begin{array}{l}\text { Triton } \\
\mathrm{X}-114\end{array}$ & $\begin{array}{l}\text { Triton } \\
X-100\end{array}$ & $\begin{array}{l}\text { Tween } \\
-80\end{array}$ & $\begin{array}{l}\text { Tween } \\
-60\end{array}$ & $\begin{array}{l}\text { Emulsifier } \\
\text {-OP }\end{array}$ \\
\hline \multirow[t]{2}{*}{$\lambda_{\max }(n m)$} & ACDP & 625 & 633 & 636 & 647 & 650 & 658 & 635 & 644 \\
\hline & ATDP & 622 & 637 & 640 & 650 & 652 & 666 & 648 & 654 \\
\hline Molar absorptivity & ACDP & 0.636 & 0.841 & 1.98 & 11.3 & 7. 65 & 2. 24 & 4.97 & 6.48 \\
\hline $\mathrm{L} / \mathrm{mol} \mathrm{cm} \times 10^{5}$ & ATDP & 0.248 & 1.02 & 3.11 & 9.85 & 2.76 & 4.79 & 5.27 & 4.84 \\
\hline
\end{tabular}

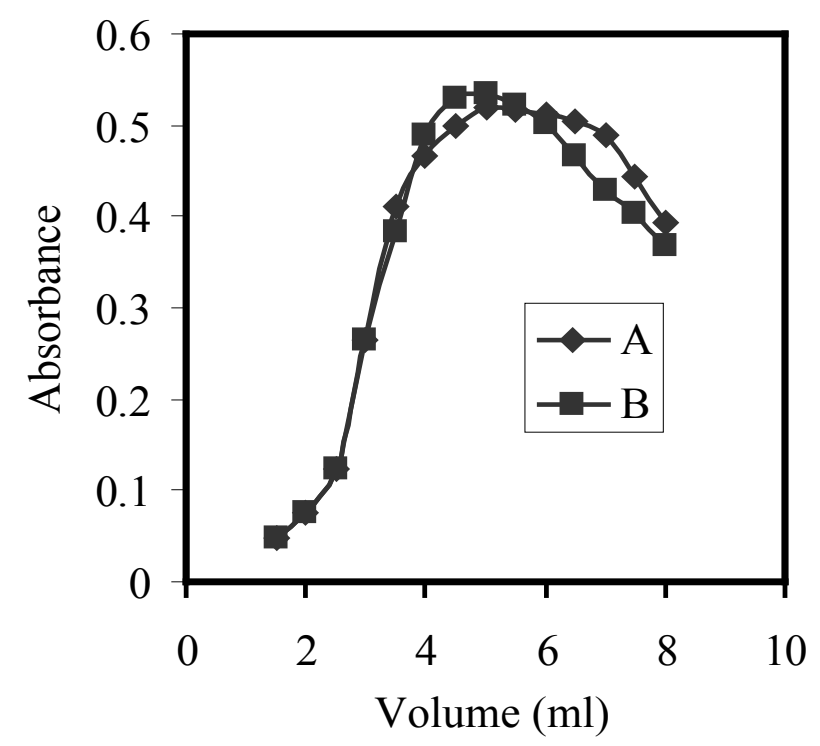

Figure 3: Effect of $2.0 \%$ Triton $\mathrm{X}-114$ on the complexation of $100 \mathrm{ng} / \mathrm{ml} \mathrm{Zn}(\mathrm{II})$ at the optimum conditions A- ACDP and B- ATDP.

of $2.0 \%$ Triton $\mathrm{X}-114$ gave constant and maximum absorbance (Figure 3). Accordingly, $5.0 \mathrm{~mL}$ of $2.0 \%$ Triton X-114 solution was recommended for 100 $\mathrm{mL}$ sample.

\section{Effect of reagent concentration}

For up to $160 \mathrm{ng}$ of $\mathrm{Zn}(\mathrm{II})$, the use of about 2.5$3.5 \mathrm{ml}$ of $2 \times 10^{-3} \mathrm{M}$ of ACDP and/or ATDP solution was found to be sufficient for a complete color enhancement. Accordingly, $3.0 \mathrm{ml}$ of $2 \times 10^{-3} \mathrm{M}$ ACDP and/or ATDP solution was added in all further measurements using $100 \mathrm{ml}$ sample.

\section{Stability of the chromogenic system}

After mixing the components, the absorbance reached its maximum within $5.0 \mathrm{~min}$ at room temperature and remained stable for $8.0 \mathrm{~h}$ in aqueous solution. The complex were stable for at least $24 \mathrm{~h}$ when extracted into the isopentyl alcohol medium.

\section{Solid phase extraction}

Different commercially available adsorbant and crosslinked polymers were examined (modified C-18 silica activated carbon, alumina and Amberlite XAD resins) It would observed that the most sensitive and selective for successful SPE to be used are Amberlite XAD resins, because of good adsorption properties such as large surface areas and good hydrophobic nature. Amberlite XAD2000 resin from all Amberlite XAD resin series was used to give the optimum results especially when grinding the particles to $0.1-0.2 \mathrm{~mm}$ size (due to increasing the surface area). Amberlite XAD-2000 is a polystyrene-divinylbenzene copolymer having specific surface area: $620 \mathrm{~m}^{2} \mathrm{~g}^{-1}$, dipole moment: 0.3 , pore size: $4.5 \mathrm{~nm}$ and bead size: $20-50$ mesh [44]. Because of these important properties, it has selected as a solid phase extractant in this work. The pale pink color of the formed complex was changed to violet after preconcentrated for 3.0 min, with Amberlite XAD-2000.

Both the enrichment and the elution were carried out on a Waters SPE device (capable of preparing 20 samples simultaneously). The flow rate was set to $20 \mathrm{ml} / \mathrm{min}$ when enriching and 1.0 $\mathrm{ml} / \mathrm{min}$ when eluting. Some experiments were carried out in order to investigate the retention of ACDP and/or ATDP and their Zn(II) complex on the resin. It was determined that the ACDP and/or ATDP and their $\mathrm{Zn}$ (II) complex were retained on the resin quantitatively when they passed the resin as an aqueous solution. The capacity of the resin for ACDP and/or ATDP was 36 and $41 \mathrm{mg}$ respectively, and that for their $\mathrm{Zn}$ (II)-complex was $28 \mathrm{mg}$ and $32 \mathrm{mg}$, respectively, in $100 \mathrm{~mL}$ of solution. In this experiment, the resin was sufficient capacity to enrich the $Z n(I I)-$ ACDP and/or ATDP complex and the excessive ACDP and/or ATDP.

In order to choose a proper eluant for the retained $L_{1}$ ACDP and/or ATDP and their $\mathrm{Zn}$ (II) complex, various organic solvents were studied. The effect of the various organic solvents was 
in the following sequence: Isopentyl alcohol > acetonitrile $>$ DMF $>$ dioxane $>$ acetone $>$ ethanol $>$ methanol. Isopentyl alcohol was therefore selected as the eluant. The experiment showed that it was easier to elute the retained ACDP and/or ATDP and their $\mathrm{Zn}$ (II) complex in a reverse direction than in a forward direction, and it is necessary to upturning the resin when eluting. In addition, 0.2 $\mathrm{ml}$ of isopentyl alcohol was sufficient to elute the ACDP and/or ATDP and their Zn(II) complex from the resin at a flow rate of $1.0 \mathrm{ml} / \mathrm{min}$ as a proper eluant.

The improvement factor, defined as the ratio of the slope of the calibration graph for the CPE method to that of the calibration graph in micellar media without preconcentration, was 1350 and 1500 using ACDP and/or ATDP. Because the amount of $\mathrm{Zn}(\mathrm{II})$ in $100 \mathrm{ml}$ of sample solution is measured after preconcentration in a final volume of $0.2 \mathrm{ml}$ isopentyl alcohol, the solution is enriched by an enrichment factor of 500 .

\section{Calibration curve and sensitivity}

The calibration curve show that Beer's law is obeyed in the concentration range of 5.0-160 ng $\mathrm{Zn}$ (II) per $\mathrm{ml}$ in the $100 \mathrm{ml}$ final solution. Ringbom optimum concentration ranges were obtained by plotting the logarithmic value of the concentration of $\mathrm{Zn}$ (II) against the transmittance percentage and the result is recorded in Table 2 .

The linear regression equation obtained was

$$
A=5.188 \mathrm{C}(\mu \mathrm{g} / \mathrm{ml})+0.0041,(r=0.9992)
$$

The molar absorptivity and Sandell sensitivity were calculated to be $1.13 \times 10^{6} \mathrm{~L} / \mathrm{mol} \mathrm{cm}$ and $0.0192 \mathrm{ng} / \mathrm{cm}^{2}$ at $647 \mathrm{~nm}$ for ACDP, whereas for ATDP were calculated to be $1.37 \times 10^{6} \mathrm{~L} \mathrm{~mol}^{-1} \mathrm{~cm}^{-1}$ and $0.0178 \mathrm{ng} \mathrm{cm}^{-2}$ at $662 \mathrm{~nm}$. The standard deviations of the absorbance measurements were calculated from a series of 13 blank solution. The limits of detection $(K=3)$ and of quantification $(K=10)$ of the method were established [45] and recorded in Table 2, according to the IUPAC definitions $\left(C_{1}=K_{0} / s\right.$ where $C_{1}$ is the limit of detection, $S_{0}$ is the standard error of blank, $s$ is the slope of the standard curve and $\mathrm{K}$ is the constant related to the confidence interval. The relative standard deviation was 1.26 and $1.56 \%$ using ACDP and ATDP, respectively, obtained from a series of ten standards each containing $50 \mathrm{ng} / \mathrm{ml}$ of $\mathrm{Zn}$ (II) in the final assay solution. On the other hand, the proposed proce- dure, which is a precision assay, is determined at different standard levels.

The sensitivities expressed as molar absorptivity, of the proposed method are compared in Table 3 with those of published spectrophotometric methods. The higher sensitivity of the proposed method is notable, greater even than that of other methods by at least 100 times [7,46-51]. The method to determine zinc by SPS, which uses zincon as reagent [52], requires the prior separation of the analyte as $\mathrm{ZnCl}_{4}^{-2}$ complex which is fixed on the anion exchanger; the reaction between zinc-chloride complex (which is not stripped from the exchanger) and zincon is then carried out on the solid phase. However, the use of the proposed method makes it possible to determine zinc without any prior separation of the analyte from the matrix. Although, the sensitivity of the 2-(4-pyridylazo)resorcinol methods [53] showed a near values of molar absorptivity (especially for $500 \mathrm{~mL}$ ), they suffer from a large values for detection and quantification limits (2.5 and $8.3 \mu \mathrm{g} / \mathrm{L}$ for $100 \mathrm{ml}$, and 0.3 and $1.1 \mu \mathrm{g} / \mathrm{L}$ for $500 \mathrm{~mL}$, respectively), in addition to interference of $\mathrm{Pb}(\mathrm{II}), \mathrm{Mn}(\mathrm{II}), \mathrm{Cu}(\mathrm{II}), \mathrm{V}(\mathrm{V}), \mathrm{Cd}(\mathrm{II}), \mathrm{Ni}(\mathrm{II})$, and $\mathrm{co}(\mathrm{II})$ ions.

\section{Effects of foreign ions}

In order to assess the possible analytical applica-

Table 2: Analytical features of the proposed procedure.

\begin{tabular}{|c|c|c|}
\hline \multirow[t]{2}{*}{ Parameter } & \multicolumn{2}{|l|}{ Value } \\
\hline & ACDP & ATDP \\
\hline Beer's law limit (ng/ml) & $5.0-160$ & $5.0-145$ \\
\hline Ringbom optimum range (ng/ml) & $10-145$ & $10-130$ \\
\hline Molar absorptivity (L/mol cm) & $1.13 \times 10^{6}$ & $1.37 \times 10^{6}$ \\
\hline Sandell sensitivity (ng/cm) & 0.0192 & 0.0178 \\
\hline Detection limit (ng/ml) & 1.5 & 1.66 \\
\hline Quantification limit (ng/ml) & 4.7 & 5.1 \\
\hline Enrichment factor & 500 & 500 \\
\hline Improvement factor & 1350 & 1350 \\
\hline \multicolumn{3}{|l|}{ Regression equation $^{\text {a }}$} \\
\hline Slope (b) & 5.118 & 5.38 \\
\hline Intercept (a) & 0.0041 & 0.0033 \\
\hline Correlation coefficient (r) & 0.9992 & 0.9996 \\
\hline RSD (\%) & 1.26 & 1.47 \\
\hline S Stoichiometric ratio (L:M) & $2: 1$ & $2: 1$ \\
\hline
\end{tabular}

${ }^{a}: A=a+b C$; where $C$ is the concentration of zinc in $\mu g / m l$. 
Table 3: Sensitivities of methods for the spectrophotometric determination of zinc.

\begin{tabular}{|l|l|l|l|}
\hline Reagent & $\lambda_{\text {max }^{\prime}}(\mathbf{n m})$ & $\begin{array}{l}\times 10^{5} \\
\text { L/mol cm }\end{array}$ & Ref. \\
\hline 2-(2-quinolylazo)-5-dimthylaminophenol & 590 & 1.22 & {$[46]$} \\
\hline 1-(2-thiazolylazo)-2-naphthol (TAN) & 590 & 2.02 & {$[47]$} \\
\hline 1-(2-pyridylazo)-2-naphthol & 560 & 7.30 & {$[48]$} \\
\hline N-Ethyl-3-carbazolecarboxaldehyde-3-thiosemicarbazone & 420 & 1.55 & {$[14]$} \\
\hline 1,3-Cyclohexanedionedithiosemicarbazone & 570 & 1.42 & {$[49]$} \\
\hline Glyoxaldithiosemicarbazone & 433 & 1.30 & {$[50]$} \\
\hline Xylenol orange and cetylpyridinium chloride & 580 & 1.11 & {$[51]$} \\
\hline 2-(4-pyridylazo)resorcinol (100 ml) & 500 & 1.50 & {$[52]$} \\
\hline 2-(4-pyridylazo)resorcinol (500 ml) & 500 & 9.40 & {$[53]$} \\
\hline Zincon (1000 ml) & 621 & 31.00 & {$[52]$} \\
\hline ACDP & 647 & 11.30 & This \\
\hline ATDP & 662 & 13.70 & work \\
\hline
\end{tabular}

Table 4: Determination of zinc in different water samples.

\begin{tabular}{|c|c|c|c|c|c|c|}
\hline \multirow[t]{2}{*}{ samples } & \multirow{2}{*}{$\begin{array}{l}\text { Added } \\
(\mu \mathrm{g} / \mathrm{L})\end{array}$} & \multicolumn{2}{|c|}{ Found a $(\mu \mathrm{g} / L)$} & \multicolumn{2}{|c|}{ Recovery (\%) } & \multirow{2}{*}{$\begin{array}{l}\text { FAAS }^{a} \\
(\mu \mathrm{g} / \mathrm{L})\end{array}$} \\
\hline & & ACDP & ATDP & ACDP & ATDP & \\
\hline \multirow[t]{3}{*}{ Sea water } & - & $14.8 \pm 0.3$ & $15.1 \pm 0.5$ & - & - & $15.0 \pm 0.5$ \\
\hline & 20.0 & $35.0 \pm 0.2$ & $35.5 \pm 0.4$ & 101.15 & 101.14 & $35.4 \pm 0.9$ \\
\hline & 40 & $54.5 \pm 0.3$ & $54.3 \pm 0.2$ & 99.45 & 98.55 & $55.1 \pm 1.2$ \\
\hline \multirow[t]{3}{*}{ River water } & - & $10.1 \pm 0.3$ & $10.0 \pm 0.6$ & - & - & $10.4 \pm 0.8$ \\
\hline & 15.0 & $24.9 \pm 0.2$ & $25.3 \pm 0.2$ & 99.20 & 101.20 & $24.7 \pm 0.7$ \\
\hline & 30 & $45.3 \pm 0.4$ & $45.2 \pm 0.4$ & 100.44 & 100.44 & $44.8 \pm 0.6$ \\
\hline \multirow[t]{3}{*}{ Waste water } & - & $72.5 \pm 0.3$ & $72.2 \pm 0.5$ & - & - & $72.7 \pm 2.3$ \\
\hline & 10.0 & $82.2 \pm 0.6$ & $82.7 \pm 0.2$ & 99.64 & 100.61 & $83.0 \pm 0.9$ \\
\hline & 20.0 & $93.1 \pm 0.2$ & $92.6 \pm 0.3$ & 100.65 & 100.43 & $92.2 \pm 1.2$ \\
\hline \multirow[t]{3}{*}{ Tap water } & - & $2.2 \pm 0.1$ & $2.4 \pm 0.2$ & & - & $2.3 \pm 0.2$ \\
\hline & 5.0 & $7.4 \pm 0.1$ & $7.2 \pm 0.2$ & 102.78 & 97.30 & $7.2 \pm 0.3$ \\
\hline & 10.0 & $12.3 \pm 0.2$ & $12.7 \pm 0.5$ & 100.82 & 102.42 & $12.1 \pm 0.4$ \\
\hline \multirow[t]{3}{*}{ Well water } & - & $7.6 \pm 0.1$ & $7.7 \pm 0.3$ & & - & $7.5 \pm 0.2$ \\
\hline & 7.5 & $15.0 \pm 0.2$ & $15.0 \pm 0.5$ & 99.34 & 101.33 & $15.1 \pm 0.2$ \\
\hline & 15 & $22.4 \pm 0.2$ & $22.5 \pm 0.6$ & 99.12 & 99.12 & $22.6 \pm 0.2$ \\
\hline
\end{tabular}

a: Average and standard deviation of four determinations.

tions of the proposed method, the effect of some foreign ions is examined, by carrying out determinations of $50 \mathrm{ng} / \mathrm{ml}$ of zinc(II) with a known amount of foreign ion solution, using the recommended analytical procedure. An error of $\pm 5.0 \%$ in absorbance reading is considered tolerable. The results indicated that $\mathrm{Mn}(\mathrm{II}), \mathrm{Mg}(\mathrm{II}), \mathrm{Mo}(\mathrm{VI})$ and $\mathrm{W}(\mathrm{VI})$ do not interfere, even present up to eight thousand folds excess. $\mathrm{Ca}(\mathrm{II}), \mathrm{Pb}(\mathrm{II}), \mathrm{Fe}(\mathrm{II}), \mathrm{Pd}(\mathrm{II}), \mathrm{Cr}(\mathrm{III}), \mathrm{Se}(\mathrm{IV})$, and $\mathrm{Zr}$ (IV) can be tolerated up to five thousand folds excess. $\mathrm{Ni}(\mathrm{II}), \mathrm{Cu}(\mathrm{II})$, and $\mathrm{Cd}(\mathrm{II})$ interfere severely even present in trace amounts. Anions like fluoride, succinate, carbonate, bicarbonate, sulphate, tartrate, thiocyanate and oxalate do not interfere in the determination even when present upto five thousand folds excess. Chloride, bromide, phosphate nitrate 
and citrate do not have any effect on the determination of zinc(II), even when present up to four thousand folds excess. Interference of $\mathrm{Cu}$ (II) can be suppressed by using $1.0 \mathrm{ml}$ of $0.3 \%$ oxalate solution as masking agent. $\mathrm{Cd}(\mathrm{II})$ and $\mathrm{Ni}(\mathrm{II})$ can be avoided by using $1.0 \mathrm{ml}$ of $0.5 \%$ thiocyanate.

\section{Analytical applications}

The method was applied to the determination of zinc in river, sea, well, tap, and waste water. The reliability of method was checked by recovery experiments and comparing the results with data obtained by FAAS analysis. The results are shown in Table 4. The proposed method gave satisfactory average recoveries, (99.12-102.78 on using ACDP, whereas on using ATDP the recoveries between 97.30-102.42 were obtained), and there is good agreement between the results of the proposed and data obtained by FAAS methods.

Aiming to demonstrate the usefulness of the proposed system a set of samples comprising several food and milk samples was analyzed. The system was run using the optimized parameters summarized in Table 2. The results of sample are shown in Table 5. Accuracy was assessed by comparing results with these obtained using FAAS. Applying the paired t-test and F-value [54] no significant difference at $95 \%$ confidence level was observed.

The method was further applied to the determination of $\mathrm{Zn}$ ions in various biological samples. The results obtained by the proposed method are compared statistically with those of FAAS method (Table 6). It can be inferred from the statistical parameters of Table 6, the Student's t-test and F-value, that the method exhibit comparable accuracy and precision. The proposed method on the other hand can be applied in routine analysis as an alternative to FAAS method. The greater sensitivity of the proposed method over FAAS makes it advantageous when low zinc concentrations need to be determined.

\section{Conclusion}

In this study, a new, simple, inexpensive, sensitive, and selective method with the $\mathrm{Zn}(\mathrm{II})$-ACDP

Table 5: Determination of zinc(II) in food samples.

\begin{tabular}{|c|c|c|c|}
\hline \multirow{3}{*}{\begin{tabular}{|l|} 
Samples \\
Vegetable samples ${ }^{\text {b }}$
\end{tabular}} & \multicolumn{2}{|l|}{ Zinc found a } & \multirow{3}{*}{$\begin{array}{l}\text { FAAS } \\
\text { method }\end{array}$} \\
\hline & \multicolumn{2}{|l|}{ Present method } & \\
\hline & ACDP & ATDP & \\
\hline $\begin{array}{l}\text { Carrot }{ }^{\mathrm{c}} \\
\text { (t- and F-test) }\end{array}$ & $\begin{array}{l}71.2 \pm 0.05 \\
(0.54 \text { and } 1.61)\end{array}$ & $\begin{array}{l}72.0 \pm 0.05 \\
(0.73 \text { and } 2.07)\end{array}$ & $71.7 \pm 0.13$ \\
\hline $\begin{array}{l}\text { Tomato }{ }^{c} \\
\text { (t- and F-test) }\end{array}$ & $\begin{array}{l}62.6 \pm 0.07 \\
(0.67 \text { and } 1.92)\end{array}$ & $\begin{array}{l}61.6 \pm 0.05 \\
(0.83 \text { and } 2.37)\end{array}$ & $61.9 \pm 0.09$ \\
\hline $\begin{array}{l}\text { Potato }{ }^{c} \\
\text { (t- and F-test) }\end{array}$ & $\begin{array}{l}50.5 \pm 0.04 \\
(0.95 \text { and } 2.55)\end{array}$ & $\begin{array}{l}49.5 \pm 0.05 \\
(0.75 \text { and } 2.41)\end{array}$ & $49.9 \pm 0.11$ \\
\hline $\begin{array}{l}\text { Rice }^{c} \\
\text { (t- and F-test) }\end{array}$ & $\begin{array}{l}22.8 \pm 0.05 \\
(1.09 \text { and } 2.84)\end{array}$ & $\begin{array}{l}23.0 \pm 0.05 \\
(0.76 \text { and } 2.13)\end{array}$ & $23.1 \pm 0.12$ \\
\hline $\begin{array}{l}\text { Wheat }{ }^{c} \\
\text { (t- and F-test) }\end{array}$ & $\begin{array}{l}34.2 \pm 0.06 \\
(0.87 \text { and } 2.13)\end{array}$ & $\begin{array}{l}33.5 \pm 0.05 \\
(0.91 \text { and } 2.28)\end{array}$ & $33.8 \pm 0.09$ \\
\hline \multicolumn{4}{|l|}{ Milk samples ${ }^{d}$} \\
\hline $\begin{array}{l}\operatorname{Cow}^{\mathrm{e}} \\
\text { (t- and F-test) }\end{array}$ & $\begin{array}{l}4.0 \pm 0.03 \\
(0.85 \text { and } 2.33)\end{array}$ & $\begin{array}{l}3.75 \pm 0.05 \\
(0.88 \text { and } 2.44)\end{array}$ & $3.9 \pm 0.07$ \\
\hline $\begin{array}{l}\text { Goat }{ }^{-} \\
\text {(t- and F-test) }\end{array}$ & $\begin{array}{l}4.4 \pm 0.04 \\
(0.73 \text { and } 2.07)\end{array}$ & $\begin{array}{l}4.6 \pm 0.05 \\
(0.82 \text { and } 2.04)\end{array}$ & $4.5 \pm 0.12$ \\
\hline $\begin{array}{l}\text { Sheep }{ }^{\mathrm{e}} \\
\text { (t- and F-test) }\end{array}$ & $\begin{array}{l}2.9 \pm 0.05 \\
(0.84 \text { and } 2.09)\end{array}$ & $\begin{array}{l}3.1 \pm 0.05 \\
(0.98 \text { and } 2.72)\end{array}$ & $3.0 \pm 0.15$ \\
\hline
\end{tabular}

${ }^{a}$ : Mean \pm S.D. $(n=6)$; ${ }^{\text {b: }}$ Concentration in $\mu g / g$; ${ }^{c}$ : Collected from Beha, Egypt; ${ }^{d}$ : Collected from Port Said, Egypt; ${ }^{\text {e: }}$ Concentration in $\mu \mathrm{g} / \mathrm{ml}$. 
Table 6: The level of zinc in some biological samples after application of the presented and FAAS procedures ( $\mathrm{N}=5$ ).

\begin{tabular}{|l|l|l|l|l|l|l|}
\hline Sample & Ligand & Concentration $(\boldsymbol{\mu g} / \mathbf{g})$ & RSD $(\%)$ & t- test & F- value & FAAS \\
\hline Femur & ACDP & $181.5 \pm 4.0$ & 1.04 & 1.04 & & $178.5 \pm 2.0$ \\
\hline & ATDP & $180.2 \pm 3.0$ & 1.26 & & 2.47 & \\
\hline Feces & ACDP & $4935 \pm 25$ & 1.15 & 1.18 & & $4933 \pm 35$ \\
\hline & ATDP & $4928 \pm 20$ & 1.41 & & 2.71 & \\
\hline Kidney & ACDP & $25 \pm 2.0$ & 1.28 & 1.21 & & $26 \pm 1.0$ \\
\hline & ATDP & $25.5 \pm 3.0$ & 1.64 & & 2.86 & \\
\hline Human hair & ACDP & $82.1 \pm 1.8$ & 1.07 & 1.77 & & $81.5 \pm 2.7$ \\
\hline & ATDP & $82.5 \pm 3.5$ & 1.22 & & 2.43 & \\
\hline \multirow{2}{*}{ Urine $^{\text {a }}$} & ACDP & $50.1 \pm 1.6$ & 0.98 & 0.84 & & $50.8 \pm 1.9$ \\
\hline \multirow{2}{*}{ Saliva ${ }^{a}$} & ATDP & $51.2 \pm 4.0$ & 1.28 & & 2.26 & \\
\hline & ACDP & $49.3 \pm 1.7$ & 0.86 & 1.11 & & $48.6 \pm 1.6$ \\
\hline & ATDP & $49.8 \pm 1.5$ & 1.15 & & 2.66 & \\
\hline
\end{tabular}

a: $\mu \mathrm{g} \mathrm{Zn}(\mathrm{II})$ per L.

and/or ATDP complex was developed for the determination of zinc in waters, food, milk, and biological, samples, for continuous monitoring to establish the trace levels of zinc in difficult sample matrices. It offers also a very efficient procedure for speciation analysis. Although many sophisticated techniques such as HPLC, AAS, FAAS, GF-AAS, ICP-AES, and ICP-MS, are available for the determination of zinc at trace levels in numerous complex materials, factors such as the low cost of the instrument, easy handling, lack of requirement for consumables, and almost no maintenance have caused spectrophotometry to remain a popular technique, particularly in laboratories of developing countries with limited budgets. The sensitivity in terms of molar absorptivity and precision in terms of relative standard deviation of the present method are very reliable for the determination of zinc in real samples down to $\mathrm{ng} / \mathrm{g}$ levels in aqueous medium at room temperature $\left(25 \pm 5^{\circ} \mathrm{C}\right)$.

\section{References}

1. HS Ferreira, WNL Dos Santos, RP Fiuza, JA Nóbrega, SLC Ferreira (2007) Determination of zinc and copper in human hair by slurry sampling employing sequential multi-element flame atomic absorption spectrometry. Microchem J 87: 128-131.

2. S Saracoglu, KO Saygi, OD Uluozlu, M Tuzen, M Soylak (2007) Determination of trace element contents of baby foods from Turkey. Food Chem 105: 280-285.

3. OD Uluozlu, M Tuzen, D Mendil, M Soylak (2007) Trace metal content in nine species of fish from the
Black and Aegean Seas, Turkey. Food Chem 104: 835840.

4. LR Mcdowell (1992) Minerals in animal and 459 human nutrition. ( $2^{\text {nd }}$ edn), Academic press, New York, USA.

5. NW Solomons, IH Rosenberg (1992) Absorption and malabsorption of mineral nutrients, Alan R Liss, New York, USA.

6. H Scherz, E Kirchhoff (2006) Trace elements in foods: Zinc contents of raw foods-A comparison of data originating from different geographical regions of the world. J Food Comp Anal 19: 420-433.

7. J Kruusma, CE Banks, L Nei, RG Compton (2004) Electroanalytical detection of zinc in whole blood. Anal Chim Acta 510: 85-90.

8. JM Flinn, D Hunter, DH Linkous, A Lanzirotti, LN Smith, et al. (2005) Enhanced zinc consumption causes memory deficits and increased brain levels of zinc. Physiol Behav 83: 793-803.

9. S Dadfarnia, CW McLeod (1994) On-line trace enrichment and determination of uranium in waters by flow injection inductively coupled plasma mass spectrometry. Appl Spectrosc 48: 1331-1336.

10.WNL Dos Santos, EGP Da Silva, MS Fernandes, RGO Araujo, ACS Costa, et al. (2005) Determination of copper in powdered chocolate samples by slurry-sampling flame atomic absorption spectrometry. Anal Bioanal Chem 382: 1099-1102.

11.K Sreenivasa Rao, T Balaji, T Prasada Rao, Y Babu, GRK Naidu (2002) Determination of iron, cobalt, nickel, manganese, zinc, copper, cadmium and lead in human hair by inductively coupled plasma-atomic 
emission spectrometry. Spectrochimica Acta Part B : Atomic Spectroscopy 57: 1333-1338.

12.K Kilian, K Pyrzynıska (2003) Spectrophotometric study of $\mathrm{Cd}(\mathrm{II}), \mathrm{Pb}(\mathrm{II}), \mathrm{Hg}(\mathrm{II})$ and $\mathrm{Zn}(\mathrm{II})$ complexes with 5,10,15,20-tetrakis(4-carboxylphenyl) porphyrin. Talanta 60: 669-678.

13.LK Shpigun, YV Shushenachev, PM Kamilova (2006) Kinetic separation in flow injection spectrophotometry: simultaneous determination of copper and zinc in a single run. Anal Chim Acta 573-574: 360-365.

14.KJ Reddy, JR Kumar, C Ramachandraiah, T Thriveni, AV Reddy (2007) Spectrophotometric determination of zinc in foods using $\mathrm{N}$-ethyl-3-carbazolecarboxaldehyde-3-thiosemicarbazone: Evaluation of a new analytical reagent. Food Chem 101: 585-591.

15.A Bagheri, M Behbahani, MM Amini, O Sadeghi, M Taghizade, et al. (2012) Simultaneous separation and determination of trace amounts of $\mathrm{Cd}$ (II) and $\mathrm{Cu}$ (II) in environmental samples using novel diphenylcarbazide modified nanoporous silica. Talanta 89: 455461.

16. M Behbahani, M Babapour, MM Amini, O Sadeghi, A Bagheri, et al. (2013) Separation/enrichment of copper and silver using titanium dioxide nanoparticles coated with poly-thiophene and their analysis by flame atomic absorption spectrophotometry. Am J Anal Chem 4: 90-98.

17.M Behbahani, A Bagheri, MM Amini, O Sadeghi, M Salarian, et al. (2013) Application of multiwalled carbon nanotubes modified by diphenylcarbazide for selective solid phase extraction of ultra-traces $\mathrm{Cd}(\mathrm{II})$ in water samples and food products. Food Chem 141: 48-53.

18. M Behbahani, A Bagheri, M Taghizadeh, M Salarian, O Sadeghi, et al. (2013) Synthesis and characterisation of nano structure lead (II) ion-imprinted polymer as a new sorbent for selective extraction and preconcentration of ultra trace amounts of lead ions from vegetables, rice, and fish samples. Food Chem 138: 2050-2056.

19.M Behbahani, M Najafi, MM Amini, O Sadeghi, A Bagheri, et al. (2013) Dithizone modified nanoporous fructose as a novel sorbent for solid-phase extraction of ultra-trace levels of heavy metals. Microchim Acta 180: 911-920.

20.M Behbahani, M Salarian, MM Amini, O Sadeghi, A Bagheri, et al. (2013) Application of a new functionalized nanoporous silica for simultaneous trace separation and determination of $\mathrm{Cd}(\mathrm{II}), \mathrm{Cu}(\mathrm{II}), \mathrm{Ni}(\mathrm{II})$, and $\mathrm{Pb}(\mathrm{II})$ in food and agricultural products. Food Anal Methods 6: 1320-1329.
21.V Camel (2003) Solid phase extraction of trace elements. Spectrochim Acta B 1177-1233.

22.VA Lemos, LSG Teixeira, MD Bazerra, ACS Costa, JT Castro, et al. (2008) New materials for solid-phase extraction of trace elements. Appl Spectrosc Rev 43: 303-334.

23.S Meesri, N Praphairaksit, A Imyim (2007) Extraction and preconcentration of toxic metal ions from aqueous solution using benzothiazole-based chelating resins. Microchem J 87: 47-55.

24.CF Poole (2003) New trends in solid-phase extraction. Trends Anal Chem 22: 362-373.

25.K Pyrzyńska, T Wierzbicki (2004) Preconcentration and separation procedures for the spectrochemical determination of platinum and palladium. Michrochim Acta 147: 59-64.

26.A Stafiej, K Pyrzynska (2008) Solid phase extraction of metal ions using carbon nanotubes. Microchem J 89: 29-33.

27.M Tabakci, M Yilmaz (2008) Sorption characteristics of $\mathrm{Cu}(\mathrm{II})$ ions onto silica gel-immobilized calixarene polymer in aqueous solutions: Batch and column studies. J Hazard Mater 151: 331-338.

28.H Tabani, AR Fakhari, A Shahsavani, M Behbahani, M Salarian, et al. (2013) Combination of graphene oxide-based solid phase extraction and electro membrane extraction for the preconcentration of chlorophenoxy acid herbicides in environmental samples. J Chromatog A 1300: 227-235.

29.M Ahmed, R Narayanaswamy (1995) A flow-cell optosensor for monitoring aluminium(III) based on immobilised eriochrome cyanine $\mathrm{R}$ (ECR) and reflectance spectrophotometry. Sci Total Environ 163: 221-227.

30.SR Segade, JF Tyson (2007) Determination of methylmercury and inorganic mercury in water samples by slurry sampling cold vapor atomic absorption spectrometry in a flow injection system after preconcentration on silica $\mathrm{C}_{18}$ modified. Talanta 71: 1696-1702.

31.S Cerutti, MF Silva, JA Gasquez, RA Olsina, LD Martinez (2003) On-line preconcentration/determination of cadmium in drinking water on activated carbon using 8-hydroxyquinoline in a flow injection system coupled to an inductively coupled plasma optical emission spectrometer. Spectrochim Acta B 58: 4350.

32.M Ghaedi, F Ahmadi, H Karimi, S Gharaghani (2006) Preconcentration and extraction of copper on activated carbon using 4- amino-2, 3-dimethyl-1phenyl-3-pyrazoline or 4-(4-methoxy benzylidenimin) 
thiophenole. J Korean Chem Soc 50: 23-31.

33. M Ghaedi, MR Fathi, F Marahel, F Ahmadi (2005) Simultaneous preconcentration and determination of copper, nickel, cobalt and lead ions content by flame atomic absorption spectrometry. Fresen Environ Bull 14: 1158-1163.

34.K Suvardhan, KS Kumar, D Rekha, B Jayaraj, GK Naidu, et al. (2006) Preconcentration and solid-phase extraction of beryllium, lead, nickel, and bismuth from various water samples using 2-propylpiperidine-1-carbodithioate with flame atomic absorption spectrometry (FAAS). Talanta 68: 735-740.

35.A Uzun, M Soylak, L Elci (2001) Preconcentration and separation with Amberlite XAD-4 resin; determination of $\mathrm{Cu}, \mathrm{Fe}, \mathrm{Pb}, \mathrm{Ni}, \mathrm{Cd}$ and $\mathrm{Bi}$ at trace levels in waste water samples by flame atomic absorption spectrometry. Talanta 54: 197-202.

36.PK Tewari, AK Singh (2002) Preconcentration of lead with Amberlite XAD-2 and Amberlite XAD-7 based chelating resins for its determination by flame atomic absorption spectrometry. Talanta 56: 735-744.

37.C Duran, HB Senturk, A Gundogdu, VN Bulut, L Elci, et al. (2007) Determination of some trace Metals in environmental samples by flame AAS following solid phase extraction with Amberlite XAD-2000 resin after complexing with 8-hydroxyquinoline. Chin J Chem 25: 196-202.

38.C Duran, M Soylak, VN Bulut, A Gundogdu, M Tufekci, et al. (2007) Speciation of $\mathrm{Cr}(\mathrm{III})$ and $\mathrm{Cr}(\mathrm{VI})$ in environmental samples after solid phase extraction on Amberlite XAD-2000. J Chinese Chem Soc 54: 625634.

39.LC Willemsons (1986) Handbook of lead chemicals, Project LC-116, International Lead Zinc Research Organization, New York, USA.

40.J Pan, Z Li, CG Hsu (1994) Anal Laboratory 13: 29-31.

41.A El-Bindary, M Hussein, R El-Boz (2015) Molecular docking, theoretical calculations and potentiometric studies of some azo phenols. J Mol Liq 211: 256-267.

42.L Elci, M Soylak, M Dogan (1992) Preconcentration of trace metals in river waters by the application of chelate adsorption on Amberlite XAD-4. Fresen J Anal Chem 342: 175-178.

43. HTS Britton (1952) Hydrogen ions. ( $4^{\text {th }}$ edn), Chapman and Hall, London, UK.
44.MJ Ahmed, M Al Mamun (2001) Spectrophotometric determination of lead in industrial, environmental, biological and soil samples using 2, 5-dimercapto-1, 3, 4-thiadiazole. Talanta 55: 43-54.

45.VA Fassel (1976) International union of pure and applied chemistry. Analytical chemistry division. Commission on spectrochemical and other optical procedures for analysis. nomenclature, symbols, units and their usage in spectrochemical analysis. II. Data interpretation. (Rules approved 1975). Anal Chem 48: 2294-2296.

46.SP Zhou, CQ Duan, HC Liu, QF Hu (2005) Study on solid phase extraction spectrophotometric determination of zinc with 2-(2-quinolylazo)-5-dimthyl-aminophenol. Guang Pu Xue Yu Guang Pu Fen Xi 25: 16671170.

47.LSG Teixeira, FRP Rocha, M Korn, BF Reis, SLC Ferreira, et al. (1999) Flow-injection solid-phase spectrophotometry for the determination of zinc in pharmaceutical preparations. Anal Chim Acta 383: 309-315.

48.L Wei, X Zhang, Y Dai, J Huang, Y Xie, et al. (2008) Online preconcentration and determination of trace amounts of zinc in nature waters. J Auto Meth \& Manag Chem 7: 1-4.

49.JJB Nevado, JAM Leyva, MR Ceba (1976) Analytical properties of 1,3-cyclohexanedione bisthiosemicarbazone monohydrochloride. Talanta 23: 257-258.

50.M Benamor, K Belhamel, MT Draa (2000) Use of xylenol orange and cetylpyridinium chloride in rapid spectrophotometric determination of zinc in pharmaceutical products. J Pharm \& Biomed Anal 23: 1033-1038.

51.K Yoshimura, H Waki, S Ohashi (1978) Ion-exchanger colorimetry-III microdetermination of zinc in water. Talanta 25: 579-583.

52.MA Herrador, AM Jimenez, AG Asuero (1987) Spectrophotometric determination of zinc in potable waters and insulin with methylglyoxal bis(4-phenyl3-thiosemicarbazone). Analyst 112: 1237-1246.

53.MF Molina, M Nechar, JM Bosque-Sendra (1998) Determiation of zinc in environmental samples by solid phase spectrophotometry: Optimization and validation study. Analytical Sciences 14: 791-797.

54.JN Miller, JC Miller (2005) Statistics and chemometrics for analytical chemistry. ( $5^{\text {th }}$ edn), Prentice Hall, England. 